\title{
Observations of the cold wake of Typhoon Fanapi (2010)
}

\author{
Rosalinda K. Mrvaljevic, ${ }^{1}$ Peter G. Black, ${ }^{2}$ Luca R. Centurioni, ${ }^{3}$ Ya-Ting Chang, ${ }^{4}$ \\ Eric A. D’Asaro, ${ }^{1}$ Steven R. Jayne, ${ }^{5}$ Craig M. Lee, ${ }^{1}$ Ren-Chieh Lien, ${ }^{1}$ I-I Lin, ${ }^{4}$ \\ Jan Morzel, ${ }^{6}$ Pearn P. Niiler (deceased), ${ }^{3}$ Luc Rainville, ${ }^{1}$ and Thomas B. Sanford ${ }^{1}$
}

Received 22 October 2012; revised 11 December 2012; accepted 14 December 2012; published 19 January 2013.

[1] Several tens of thousands of temperature profiles are used to investigate the thermal evolution of the cold wake of Typhoon Fanapi, 2010. Typhoon Fanapi formed a cold wake in the Western North Pacific Ocean on 18 September characterized by a mixed layer that was $>2.5^{\circ} \mathrm{C}$ cooler than the surrounding water, and extending to $>80 \mathrm{~m}$, twice as deep as the preexisting mixed layer. The initial cold wake became capped after 4 days as a warm, thin surface layer formed. The thickness of the capped wake, defined as the $26^{\circ} \mathrm{C}-27^{\circ} \mathrm{C}$ layer, decreased, approaching the background thickness of this layer with an e-folding time of 23 days, almost twice the e-folding lifetime of the Sea Surface Temperature (SST) cold wake (12 days). The wake was advected several hundreds of kilometers from the storm track by a preexisting mesoscale eddy. The observations reveal new intricacies of cold wake evolution and demonstrate the challenges of describing the thermal structure of the upper ocean using sea surface information alone. Citation: Mrvaljevic, R. K., P. G. Black, L. R. Centurioni, Y.-T. Chang, E. A. D'Asaro, S. R. Jayne, C. M. Lee, R.-C. Lien, I.-I. Lin, J. Morzel, P. P. Niiler, L. Rainville, and T. B. Sanford (2013), Observations of the cold wake of Typhoon Fanapi (2010), Geophys. Res. Lett., 40, 316-321, doi:10.1029/2012GL054282.

\section{Introduction}

[2] Tropical cyclones (TCs) form cold wakes along and usually to the right (Northern Hemisphere) or left (Southern Hemisphere) of the storm track through a combination of air-sea heat transfer, upwelling, and mixing of the upper ocean [Leipper, 1967; Price, 1981; Black, 1983; Shay, 2010, and references therein]. The lifetime of these wakes, as measured by Sea Surface Temperature (SST), varies from a few days to a few weeks [Black, 1983; Cione, et al., 2000; Lin et al., 2003a, 2003b; Price et al., 2008; Sriver et al.,

All Supporting Information may be found in the online version of this article.

${ }^{1}$ Applied Physics Laboratory and School of Oceanography, University of Washington, Seattle, Washington, USA.

${ }^{2}$ SAIC/NRL, Monterey, California, USA.

${ }^{3}$ Scripps Institution of Oceanography, University of California, San Diego, California, USA.

${ }^{4}$ Institute of Oceanography, National Taiwan University, Taipei, Taiwan.

${ }^{5}$ Woods Hole Oceanographic Institution, Woods Hole, Massachusetts, USA.

${ }^{6}$ Rosetta Consulting, Boulder, Colorado, USA.

Corresponding author: Rosalinda K. Mrvaljevic, Applied Physics Laboratory and School of Oceanography, University of Washington, Seattle, Washington, USA. (rmrvaljevic@apl.washington.edu)

(C)2012. American Geophysical Union. All Rights Reserved. 0094-8276/13/2012GL054282
2008], with an average e-folding time of about a week [Jansen et al., 2010; Dare and McBride, 2011]. However, as shown here, the SST cold wake does not adequately represent the much deeper (order $100 \mathrm{~m}$ ) thermal anomaly created by storm mixing.

[3] Cold wakes sometimes reappear in SST observations after a period of warming [e.g. Price et al., 2008], but detailed observations of this phenomenon are rare with subsurface observations focusing mostly on cold wake formation and the first few days of evolution [Price, 1981, 1983; Dickey et al., 1998; D'Asaro, 2003; D'Asaro et al., 2007; Black et al., 2007; Sanford et al., 2011]. Detailed subsurface observations of cold wakes for many weeks are necessary to understand their lifetime and evolution.

[4] The thermal structure of the upper ocean is an important factor determining the intensity of a TC [Emanuel, 1999]. Estimates have been made based on remotely sensed sea surface temperature and sea surface height anomaly (SSHA), assuming a two-layer reduced gravity ocean model (TLM) with a standard shape for the subsurface temperature profile based on climatology [Shay et al., 2000; Pun et al., 2007; Goni et al., 2009]. The temperature profile in a TC cold wake is formed by different processes than the climatological profile and, as we show here for Typhoon Fanapi (2010), is not well reproduced with the two-layer model.

[5] We report observations of the evolution of the cold wake of Typhoon Fanapi from September through November 2010 as part of the ITOP (Impact of Typhoons on the Ocean in the Pacific [D'Asaro et al., 2011; Pun et al., 2011]) program. The combination of air-deployed instruments, strategically placed moorings and a flexible ship schedule allowed ITOP to overcome the difficulties posed by the unpredictability and rapid evolution of typhoons and the long duration of their wakes. Typhoon Fanapi formed on 14 September, slowing and executing an S-shaped track as it intensified. It then continued westward reaching category 3 status before crossing Taiwan on 19 September and dissipating after landfall on mainland China on 22 September. Fanapi formed a cold wake with SSTs $>2.5^{\circ} \mathrm{C}$ cooler than the surrounding waters (Figure 2). This paper briefly describes the data and observation methods (Section 2), defines parameters of the cold wake (Section 3 ), discusses the space and time evolution of both the SST and subsurface cold wakes, and finally estimates the wake lifetime and its geographical variability (Section 4). Section 5 summarizes and discusses potential mechanisms responsible for the wake's evolution.

\section{Data}

[6] Observations of upper ocean thermal structure extended from before the passage of Typhoon Fanapi to over 
2 months after its passage (see Supporting Information for details of each measurement platform). Two moorings that measured temperature profiles during the entire season were located at approximately $22^{\circ} \mathrm{N}, 124^{\circ} \mathrm{E}$ (A4) and $21^{\circ} \mathrm{N}, 123^{\circ} \mathrm{E}$ (SA2), where historically the strongest Typhoon-associated winds are most likely to occur. Seventy-two AXBTs (Airborne eXpendable BathyThermograph) were deployed between 15 and 20 September during four survey and reconnaissance flights. On the 17 September flight, seven EM-APEX (Electro-Magnetic Autonomous Profiling Explorer) floats [Sanford et al., 2005] and eight ADOS (Autonomous Drifting Ocean Stations) drifters [Black et al., 2007; Centurioni, 2010] were air deployed in a line perpendicular to the 24-hour forecast storm track with spacing of $\sim 45 \mathrm{~km}$. This deployment was carefully designed to maximize cross-track resolution and range while accounting for forecast error. Typhoon Fanapi passed over this line 24 hours later on 18 September. Six additional ADOS drifters and three SUPER drifters were air deployed on 19, 20, and 21 September into the cold wake. The EM-APEX floats each transmitted data for 10 days. With a few exceptions, the ADOS and SUPER drifters transmitted data for between $\sim 20$ days and several months. The $R / V$ Revelle arrived in the region on 21 September and surveyed the wake with an underway CTD (UCTD) for 3 weeks, ending on 11 October and deployed nine Seagliders [Eriksen et al., 2001], most remaining there until early November.

[7] All instruments measured temperature profiles but not all measured salinity. Salinity made only a small ( $15 \%)$ contribution to the density change as the cold wake formed. Therefore, only temperature is analyzed in this study. The depth resolution of the temperature profiles varied between the instruments. The high-time resolution vertical profiles from the EM-APEX floats, UCTD, AXBT, and Seagliders were processed into $1 \mathrm{~m}$ depth bins. ADOS and mooring temperatures had variable depth resolution between 4 and $25 \mathrm{~m}$ (see Supporting Information). Altogether, this array produced several tens of thousands of temperature profiles in the region $122^{\circ} \mathrm{N}-132^{\circ} \mathrm{N}$ and $19^{\circ} \mathrm{E}-27^{\circ} \mathrm{E}$ (henceforth, the Typhoon Fanapi region; see Figure 1) between 1 September and 1 November.

[8] Additional SST measurements were obtained from the remote sensing system (RSS) microwave-only optimally interpolated (MW OI) SST product, which gives the estimated daily minimum ( $~ 8 \mathrm{AM}$ local time) $0.25^{\circ}$ gridded SST (Figure 2). This SST product, among the many options, showed close agreement with the shallowest temperature from each profile. These, however, were often up to $10 \mathrm{~m}$ deep, producing up to $\sim 0.5^{\circ} \mathrm{C}$ difference between the in situ SST and the MW OI SST (see Figure 4).

\section{Defining the Cold Wake}

[9] Two EM-APEX floats (highlighted in Figure 1) and two ADOS drifters sampled the cold wake formation and evolution near the center of Typhoon Fanapi. The eye passed almost directly over EM-APEX 4910 (and ADOS 21523), while EM-APEX 4907 (and ADOS 21952) profiled approximately $35 \mathrm{~km}$ to the right (NNE) of the track, just beyond the $23 \mathrm{~km}$ radius of maximum surface winds. As Typhoon Fanapi passed, the mixed layer in this region cooled (Figures 3a-3c) from $\sim 29.5^{\circ} \mathrm{C}$ (day 260) to $\sim 26.5^{\circ} \mathrm{C}$ (day 261) and deepened from 40 to $60 \mathrm{~m}$ to $>80 \mathrm{~m}$ (Figures $4 \mathrm{~b}$ and $4 \mathrm{c}$ ). Over the next week, the surface

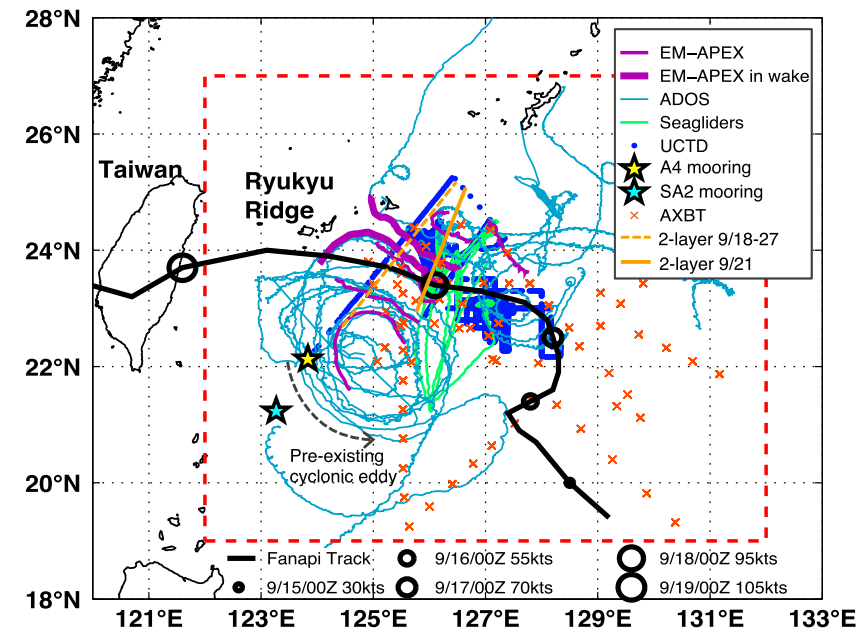

Figure 1. Typhoon Fanapi (black line) executed an S-shaped track as its intensity (circles) increased. Temperature profiles were measured by 7 EM-APEX floats, 19 ADOS drifters, 9 Seagliders, 3 weeks of UCTD, 2 moorings, and 72 AXBTs (see legend). Float and drifter tracks show a cyclonic eddy south of the storm track. Altimeter data (orange) were used for two-layer model thermal estimates (Figure 3hi). The red dotted rectangle is the Typhoon Fanapi region.

warmed by $1-2{ }^{\circ} \mathrm{C}$ (Figure $4 \mathrm{a}$ ), creating a shallow warm layer capping the cold wake by 22 September (Figure $4 \mathrm{c}$ ).

[10] In the wake (Figures $3 \mathrm{a}$ and $3 \mathrm{~b}$ ), the $26^{\circ} \mathrm{C}$ isotherm marks the base of the mixed layer, while the $27^{\circ} \mathrm{C}$ isotherm marks the bottom of its capping surface layer. Other platforms corroborate this: an ADOS drifter (Figure 3c), two Seagliders (Figure 3d), the A4 mooring (Figure 3e), and two cross-sections from the shipboard UCTD (Figures $3 \mathrm{f}$ and $3 \mathrm{~g}$ ). Each shows a thickened $26^{\circ} \mathrm{C}-27^{\circ} \mathrm{C}$ layer, as do the profiles in Figure $4 \mathrm{c}$. We interpret this as the subsurface signature of Typhoon Fanapi's cold wake.

[11] The term "cold wake" has traditionally referred to what we will specify as the "SST cold wake." We thus make the following definitions: the SST cold wake of Typhoon Fanapi is the patch of reduced SST (cooler by $>1 / e$ of the maximum cooling). The cold wake is the layer of reduced stratification above the $26^{\circ} \mathrm{C}$ isotherm. When the cold wake is capped, a layer warmer than $27^{\circ} \mathrm{C}$ overlies what is now the subsurface cold wake. Thus, the wake thickness is the difference in depth between the $26^{\circ} \mathrm{C}$ and $27^{\circ} \mathrm{C}$ isotherms for a subsurface (capped) cold wake and the depth of the $26^{\circ} \mathrm{C}$ for a cold wake that is not capped. The background thickness is the difference in depth between the $26^{\circ} \mathrm{C}$ and $27^{\circ} \mathrm{C}$ isotherms in the absence of a cold wake. The term thickness without the qualifier of wake or background refers to the thickness of the $26^{\circ} \mathrm{C}-27^{\circ} \mathrm{C}$ layer. The lifetime of the SST cold wake is the time for SST to warm to $\mathrm{T}_{0}-\Delta \mathrm{T} / e$, where $\mathrm{T}_{0}$ is the prestorm SST and $\Delta \mathrm{T}$ is the maximum SST cooling that occurred. The lifetime of the subsurface cold wake is the time for the thickness to decrease to $\Delta \mathrm{Th} / e$, where $\Delta \mathrm{Th}$ is the maximum thickening of the $26^{\circ} \mathrm{C}-27^{\circ} \mathrm{C}$ layer.

\section{Evolution of the Cold Wake}

\subsection{SST Cold Wake}

[12] The spatial and temporal evolution of the SST cold wake is shown in Figures 2 and 3a, respectively. As 


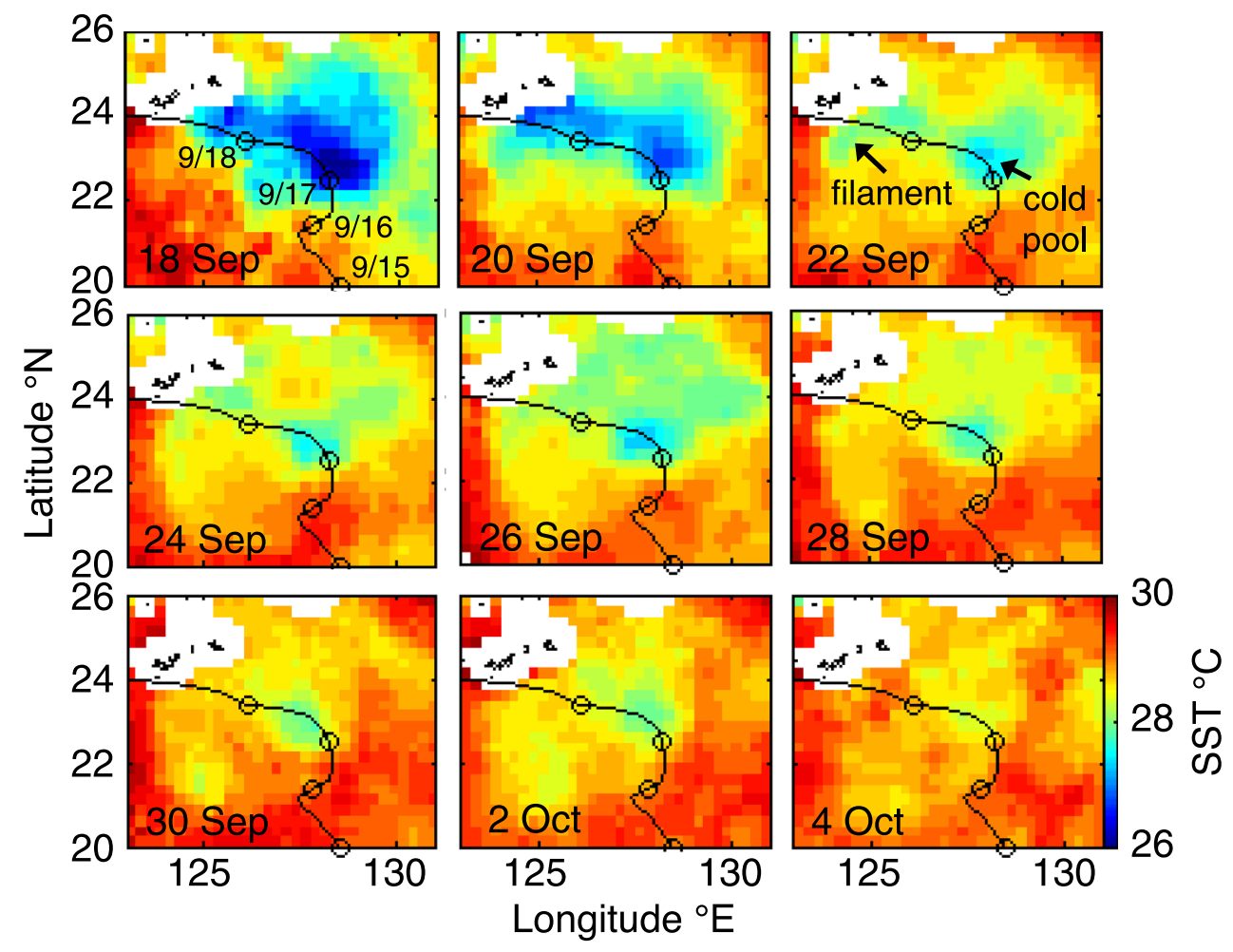

Figure 2. The decay of Typhoon Fanapi's cold wave from microwave SST; images every 2 days. SST warmed rapidly for the first few days and then more slowly over the following weeks. The eastern "cold pool" persisted, while the western "filament" advected around the cyclonic eddy.

Typhoon Fanapi passed, SST cooled from prestorm values of $\sim 29.5^{\circ} \mathrm{C}$ to $\sim 28.7^{\circ} \mathrm{C}$ over a wide region. The cold wake consisted of a western "filament" $\left(26.5^{\circ} \mathrm{C}\right)$ and an eastern "cold pool" $\left(\sim 25.5^{\circ} \mathrm{C}\right)$ near $23^{\circ} \mathrm{N} 127^{\circ} \mathrm{E}$. The cold pool warmed to $\mathrm{T}_{0}-\Delta \mathrm{T} / e \approx 28^{\circ} \mathrm{C}$ by 30 September (year day 273), for a SST cold wake lifetime of 12 days.

[13] The SST warmed in two phases, at first rapidly ( $\sim 4$ days) and then more slowly ( $\sim 10$ days), but never warmed above the $28.7^{\circ} \mathrm{C}$ background SST (Figure 4a). If $\mathrm{T}_{0}$ is set to the $28.7^{\circ} \mathrm{C}$ background SST instead of the $29.5^{\circ} \mathrm{C}$ prestorm SST, the cold pool warms to $\mathrm{T}_{0}-\Delta \mathrm{T} / e$ $27.5^{\circ} \mathrm{C}$ by 23 September (year day 266), coinciding with the formation of the cap and the end of the rapid cooling phase. The filament part of the wake followed a similar warming pattern. This two-phase warming trend is not unique to Typhoon Fanapi's cold wake but is a common warming pattern for cold wakes [Dare and McBride, 2011].

[14] Spatially, the cold wake of Typhoon Fanapi was inhomogeneous. In the first SST image (Figure 2a), the coldest water is in the eastern "cold pool" with a narrower "filament" extending westward. The cold pool remains nearly stationary, maintaining its rounded shape and remains cooler than the western part. Meanwhile, the western part of the wake warms more quickly and is advected cyclonically around a large $(>200 \mathrm{~km}$ diameter) eddy centered near $\sim 22^{\circ} \mathrm{N}, 125^{\circ} \mathrm{E}$. This cyclonic advection, apparent in many of the EM-APEX and ADOS trajectories (see Figure 1), carries the wake past mooring A4 $200 \mathrm{~km}$ south of the track. Indeed, subsurface cold wake signatures with thickness up to $\sim 70 \mathrm{~m}$ appear intermittently at the A4 mooring starting $\sim 5$ days after the storm passage (Figure 3e). The eddy appears to have stretched this part of the subsurface cold wake to at least $600 \mathrm{~km}$ long within a week, roughly a factor of 2 longer than its initial size.

\subsection{The $26^{\circ} \mathrm{C}-27^{\circ} \mathrm{C}$ Layer}

[15] The temporal evolution of the subsurface cold wake thickness using all temperature profiles is shown in Figure 4b. Prior to Typhoon Fanapi's passage, the maximum thickness was $\sim 25 \mathrm{~m}$. This rapidly increased to over $110 \mathrm{~m}$ on 18 September (year day 261) immediately following Typhoon Fanapi's passage. The maximum thickness then decreased, reaching a minimum 24 days later (12 October, yearday 285) and increasing only slightly over the next 16 days. On 28 October (year day 301), Typhoon Chaba passed over the wake remnant, outcropping the $27^{\circ} \mathrm{C}$ isotherm and forming a new mixed layer.

[16] The lifetime of Typhoon Fanapi's subsurface cold wake was determined by comparing its thickness to three estimates of background thicknesses; the prestorm thickness, the thickness computed using Argo profiles in the region for 2000-2010, and the thickness observed at the mooring A4. The median thickness for all three of these backgrounds was $<20 \mathrm{~m}$, thus making the maximum thickening of the $26^{\circ} \mathrm{C}-27^{\circ} \mathrm{C}$ layer, $\Delta \mathrm{Th}=110 \mathrm{~m}-20 \mathrm{~m}=90 \mathrm{~m}$. Thickness observations in the region of the subsurface cold wake approached $\Delta \mathrm{Th} / e \approx 33 \mathrm{~m}$ around 11 October (year day 284). Thus, 23 days is the conservative estimate for the lifetime of the subsurface cold wake of Typhoon Fanapi, almost twice the SST cold wake lifetime.

[17] A sequence of potential temperature profiles summarizes the temporal evolution of the cold wake of Typhoon Fanapi (Figure 4c). The storm replaces the warm, shallow prestorm mixed layer with a deeper, colder mixed 

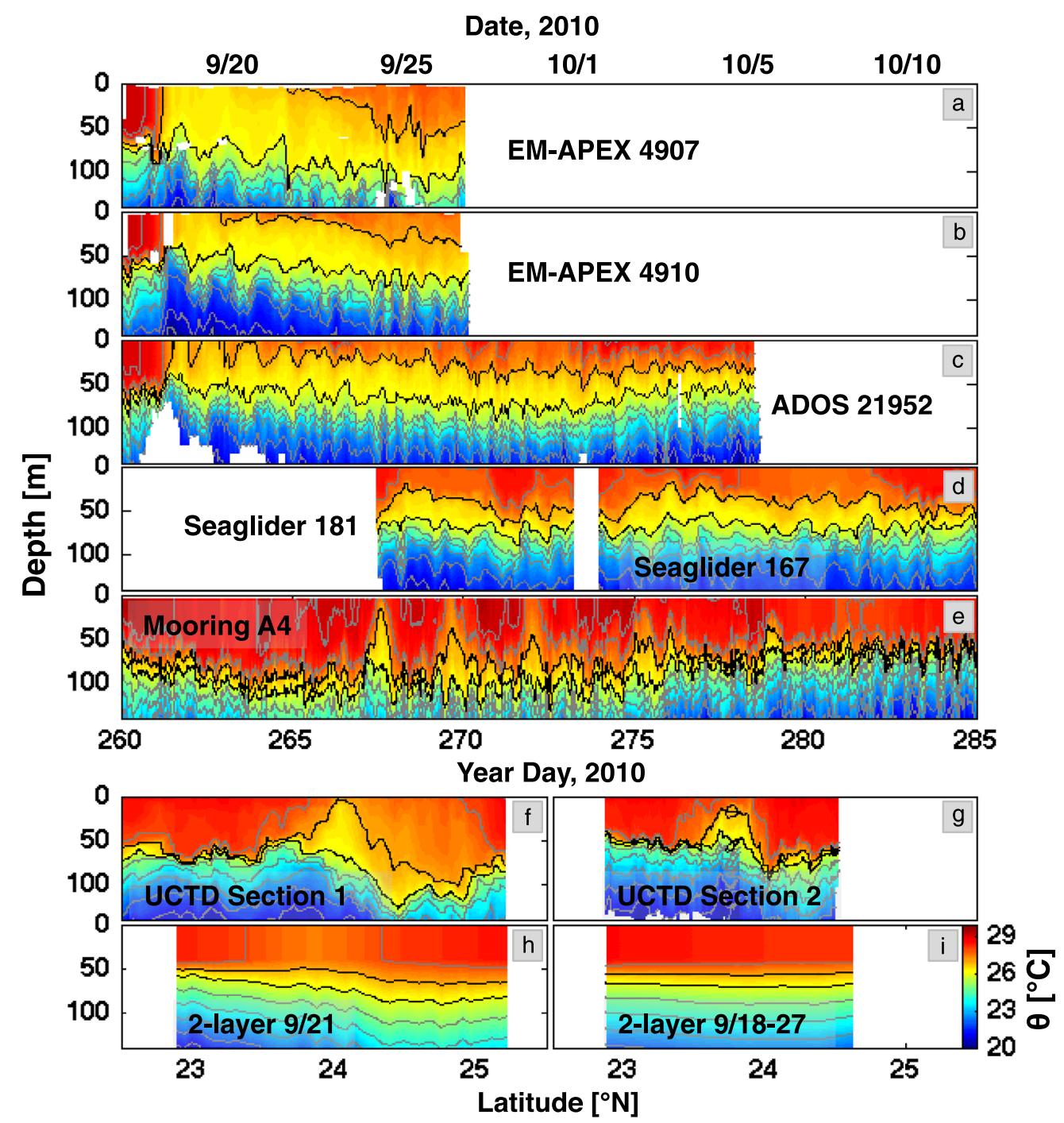

Figure 3. Potential temperature between 17 September and 12 October (contour interval $1^{\circ} \mathrm{C}$ ) from selected floats and drifters (a-c), Seagliders (d), and a mooring (e). Wake cross sections from the ship-board UCTD around 22 September (year day 265) (f) and 23 September (year day 266) (g) and from a two-layer reduced gravity model [Shay et al., 2000; Pun et al., 2007; Goni et al., 2009]) estimate of the cross section using a single altimeter pass (track 203 of NASA's Jason-2 altimeter) on 21 September (h), and using a 10 day map of SSHA from $18-27$ September (i). The $26^{\circ} \mathrm{C}$ and $27^{\circ} \mathrm{C}$ isotherms (highlighted contours) show the thickness of the cold wake. Vertical displacements of the isotherms reflect storm-induced upwelling, inertial motions (period 30 hours) and internal tides, which are strong in this region. The TLM fails to display the subsurface cold wake signature $(\mathrm{h})$.

layer, that is, the cold wake. A new warmer mixed layer caps the cold wake after 4-5 days and thickens over the following days as the stratification in the subsurface cold wake strengthens slightly. Finally, a new cold wake forms as Typhoon Chaba passes through the region, erasing any remnants of Typhoon Fanapi's cold wake.

\subsection{Two-Layer Model Wake Thermal Structure Estimate}

[18] Two estimates (based on gridded and along track SSHA data) of Typhoon Fanapi's cold wake are also made with a two-layer model (TLM) [Shay et al., 2000; Pun et al., 2007; Goni et al., 2009] (Figures 3h and 3i). The TLM cannot resolve the thermal structure of the subsurface cold wake even with a higher resolution single track SSHA (Figure $3 \mathrm{~h}$ ), probably because of the simplistic two-layer assumption and the lack of vertical resolution in the upper ocean column (see section 5).

\section{Summary and Discussion}

[19] Before Typhoon Fanapi's passage, SST in the region was $\sim 29.5^{\circ} \mathrm{C}$, and the mixed layer was $\sim 40 \mathrm{~m}$ thick. Up to $4{ }^{\circ} \mathrm{C}$ of cooling occurred as a result of Typhoon Fanapi's passage. A spatially nonuniform cold wake developed on 18 September (year day 261), initially with SST of $\sim 26.5^{\circ} \mathrm{C}$ in the western filament and $>26^{\circ} \mathrm{C}$ in the eastern cold pool and with mixed layer depths of $>80 \mathrm{~m}$. Rapid warming occurred in the first $\sim 4$ days as a thin mixed layer ("cap" with $\mathrm{T}>27^{\circ} \mathrm{C}$ ) formed over the cold wake. On 22 September (year day 265), the warming slowed and persisted over the next $\sim 10$ days. The SST cold wake warmed in two 

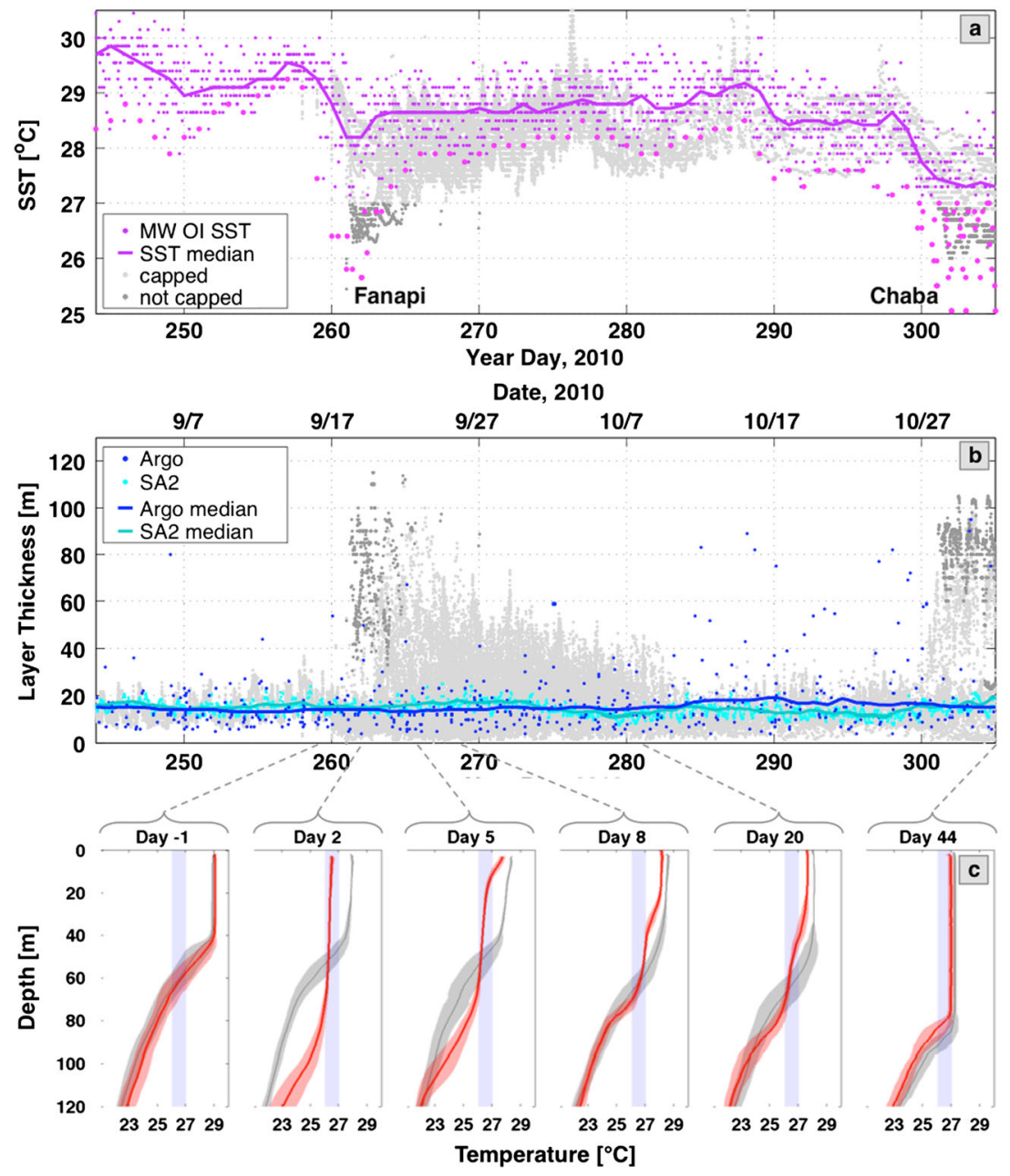

Figure 4. a) Time series of microwave SST (magenta) and ITOP in situ data (gray) in the Typhoon Fanapi region. Microwave SST values averaged $>0.5^{\circ} \mathrm{C}$ warmer than in situ SST, likely due to the depth of the in situ SST as well as errors and finite spatial resolution of microwave SST. b) Time series of the observed thickness of the $26^{\circ} \mathrm{C}$ to $27^{\circ} \mathrm{C}$ layer, including ITOP (gray) and 2000-2010 Argo profiles (dark blue) in this region. SA2 (teal) are data from the southern mooring, $\sim 21^{\circ} \mathrm{N} 123^{\circ} \mathrm{E}$. c) Summary of potential temperature profiles from selected instruments inside (red) and outside (gray) Fanapi's cold wake. The lines and shading are, respectively, the mean and standard deviation of all profiles over an inertial period from a representative instrument. The $26^{\circ} \mathrm{C}-27^{\circ} \mathrm{C}$ layer is shown in blue shading. The profiles were chosen to illustrate the most important stages in the life of the wake, while ignoring its geographical variations. Thus, the first three profiles represent the filament region while the last three profiles are from the cold pool region.

phases, with an e-folding time of 12 days. The warm cap deepened as the subsurface cold wake (defined as the anomalously thick thermostad between the $27^{\circ} \mathrm{C}$ and $26^{\circ} \mathrm{C}$ isotherms) thinned, taking $\sim 25$ days to recover to background thickness (defined by Argo climatology and southern mooring observations). Thus, the subsurface cold wake of Typhoon Fanapi persisted for twice as long as the SST cold wake, although SST never recovered to pre-Fanapi temperatures before Typhoon Chaba caused widespread cooling in the region starting on 28 October (year day 301).

[20] The cold wake of Typhoon Fanapi formed and evolved in two pieces, the filament to the west and the cold pool to the east. Several factors likely contribute to this dual-lobed development, including storm behavior and preexisting ocean conditions. The cold pool formed near where Fanapi stalled and changed direction and was thus subject to a slowly moving storm for an extended period, while the filament formed where Fanapi moved more rapidly and linearly over the ocean. The two pieces of the cold wake evolved differently due predominantly to the mesoscale eddy field. The cold pool experienced minimal eddy advection, while the filament was advected and strained by a preexisting cyclonic eddy [Lin et al., 2008]. Other factors, such as track curvature, topography, and storm-induced currents, may also have contributed to the unique formation and evolution of Typhoon Fanapi's cold wake.

[21] The warm cap observed for Typhoon Fanapi is likely a common feature of cold wakes that form during the warm season [Price et al., 2008]. Sunny conditions and light winds likely lead to the formation of the warm cap, which may isolate the cold wake from the surface and preserve it for longer than surface observations indicate. Such a capped wake represents a three-layer system, with the cap being the additional layer.

[22] The strong advection and straining of Typhoon Fanapi's wake is likely a particular characteristic of tropical 
cyclone wakes in the Western Pacific and other regions of strong mesoscale activity. In such regions, TC cold wakes are likely to travel significant distances from where they are formed, making subsurface cool anomalies difficult to associate with the parent storm. Thus, their impacts on regional heat budgets and on preconditioning the ocean response to additional storms may extend much further than the local region of the typhoon track and be difficult to track.

[23] Acknowledgments. This work is primarily supported by the U.S Office of Naval Research, with additional support from the National Science Foundation and the National Science Council, Taiwan. The authors would like to thank the whole ITOP team, including the US Airforce 53rd Squadron "Hurricane Hunters" for surveying of and instrument deployment in Typhoon Fanapi, as well as the captain and crew of the R/V Roger Revelle. Pat Harr helped plan the flights based on highly accurate typhoon forecasting provided by Grant Elliot. These observations would not have been possible without the dedicated work by John Dunlap and Avery Snyder (EM-APEX floats), Mike Ohmart (deployed floats and drifters), Jason Gobat, Adam Huxtable, and Geoff Shilling (Seagliders). Andrew Penny processed the AXBT data. The Joint Typhoon Warning Center provided the storm track data. Appreciation goes also to Jim Price and two anonymous reviewers for thoughtful comments.

\section{References}

Black, P. G. (1983), Ocean temperature changes induced by tropical cyclones, PhD thesis, The Pennsylvania State University, 278.

Black, P. G., E. A. D’Asaro, W. M. Drennan, J. R. French, P. P. Niiler, T. B. Sanford, E. J. Terrill, E. J. Walsh, and J. A. Zhang (2007), Air-sea exchange in hurricanes: Synthesis of observations from the Coupled Boundary Layer Air-Sea Transfer Experiment, Bull. Amer. Meteor. Soc., 88, 357-374, doi:10.1175/BAMS-88-3-357.

Centurioni, L. R. (2010), Observation of large-amplitude nonlinear internal waves from a drifting array: Instruments and methods, J. Atmos. Ocean. Tech., 27(10), 1711-1731, doi:10.1175/2010JTECHO774.1.

Cione, J. J., P. G. Black, and S. H. Houston, (2000), Surface observations in the hurricane environment, Mon. Wea. Rev., 128(5), 1550-1561, doi:10.1175/1520-0493(2000)128 < 1550:SOITHE > 2.0.CO;2

Dare, R. A., and J. L. McBride (2011), Sea surface temperature response to tropical cyclones, Mon. Wea. Rev., 139, 3798-3808, doi:10.1175/MWRD-10 05019.1.

D'Asaro, Eric A. (2003), The ocean boundary layer below Hurricane Dennis, J. Phys. Oceanogr., 33, 561-579, doi:10.1175/1520-0485 (2003) $033<0561$ :TOBLBH $>2.0 . \mathrm{CO} ; 2$.

D’Asaro, E. A., T. B. Sanford, P. P. Niiler, and E. J. Terrill (2007), Cold wake of Hurricane Frances, Geophys. Res. Lett., 34, L15609, doi:10.1029/2007GL030160.

D’Asaro, E., P. Black, L. Centurioni, P. Harr, S. Jayne, I.-I. Lin, C. Lee, J. Morzel, R. Mrvaljevic, P. P. Niiler, L. Rainville, T. Sanford, and T.Y. Tang (2011), Typhoon-ocean interaction in the western North Pacific: Part 1, Oceanography 24(4), 24-31, doi:10.5670/oceanog.2011.91.

Dickey, T., D. Frye, J. McNeil, D. Manov, N. Nelson, D. Sigurdson, H. Jannasch, D. Siegel, T. Michaels, and R. Johnson (1998), Upper-ocean temperature response to Hurricane Felix as measured by the Bermuda Testbed Mooring, Mon. Wea. Rev., 126, 1195-1201.

Emanuel, K. (1999), Thermodynamic control of hurricane intensity, Nature, 401, 665-669, doi:10.1038/44326.
Eriksen, C. C., T. J. Osse, R. D. Light, T. Wen, T. W. Lehman, P. L. Sabin, J. W. Ballard, and A. M. Chiodi (2001), Seaglider: A long-range autonomous underwater vehicle for oceanographic research, IEEE J. Oceanic Eng., 26(4).

Goni, G., M. DeMaria, J. Knaff, C. Sampson, I. Ginis, F. Bringas, A. Mavume, C. Lauer, I.-I. Lin, M. M. Ali, P. Sandery, S. Ramos-Buarque, K. Kang, A. Mehra, E. Chassignet, and G. Halliwell, (2009), Application of satellite-derived ocean measurements to tropical cyclone intensity forecasting, Oceanography, 22(3), 190-197, doi:10.5670/oceanog.2009.78

Jansen, M. F., R. Ferrari, and T.A. Mooring (2010), Seasonal versus permanent thermocline warming by tropical cyclones, Geophys. Res. Lett., 37, L03602, doi:10.1029/2009GL041808.

Leipper, Dale F. (1967), Observed ocean conditions and Hurricane Hilda, 1964, J. Atmos. Sci., 24(2), 182-186, doi:10.1175/1520-0469(1967) $024<0182$ :OOCAHH > 2.0.CO;2.

Lin, I.-I., W. T. Liu, C.-C. Wu, J. C. H. Chiang, and C.-H. Sui (2003a), Satellite observations of modulation of surface winds by typhoon-induced upper ocean cooling, Geophys. Res. Lett., 30(3), 1131, doi:10.1029/ 2002 GL015674.

Lin, I.-I., W. T. Liu, C.-C. Wu, G. T. F. Wong, C. Hu, Z. Chen, W.-D. Liang, Y. Yang, and K.-K. Liu (2003b), New evidence for enhanced ocean primary production triggered by tropical cyclone, Geophys. Res. Lett., 30(13), 1718, doi:10.1029/2003GL017141.

Lin, I.-I., C.-C. Wu, I.-F. Pun, and D.-S. Ko (2008), Upper-ocean thermal structure and the western North Pacific category 5 typhoons. Part I: Ocean features and the category 5 typhoons' intensification, Mon. Wea. Rev., 136, 3288-3306, doi:10.1175/2008MWR2277.1

Price, J. F. (1981), Upper ocean response to a hurricane, J. Phys. Oceanogr, 11, 153-175.

Price, J. F. (1983), Internal wave wake of a moving storm: Part I: Scales, energy budget, and observations, J. Phys. Oceanogr., 13, 949-965, doi:10.1175/1520-0485(1983)013<0949:IWWOAM > 2.0.CO;2.

Price, J. F., J. Morzel, and P. P. Niiler (2008), Warming of SST in the cool wake of a moving hurricane, J. Geophys. Res., 113, C07010, doi:10.1029/2007JC004393.

Pun, I. F., Lin, I.I., C. -R. Wu, D. -S. Ko, and W. -T. Liu. 2007. Validation and application of altimetry-derived upper ocean thermal structure in the western North Pacific Ocean for typhoon intensity forecast, IEEE Transactions On Geoscience and Remote Sensing, 45(6), 1616-1630, doi:10.1109/TGRS.2007.895950, Jun. 2007

Pun, I. F., Y.-T. Chang, I.-I. Lin, T. Y. Tang, and R.-C. Lien (2011), Typhoon-ocean interaction in the western North Pacific: Part 2, Oceanography 24(4), 32-41, doi:10.5670/oceanog.2011.92.

Sanford, T. B., J. H. Dunlap, J. A. Carlson, D. C. Webb, J. B. Girton (2005), Autonomous velocity and density profiler: EM-APEX, in Proceedings of the IEEE/OES Eighth Working Conference on Current Measurement Technology, pp. 152-156, doi:10.1109/CCM.2005.1506361.

Sanford, T. B., J. F. Price, J. B. Girton (2011), Upper-ocean response to Hurricane Frances (2004) observed by profiling EM-APEX floats, $J$. Phys. Oceanogr., 41, 1041-1056, doi:10.1175.2010JPO4313.1

Shay, L. K., G. J. Goni, P. G. Black (2000), Effects of a warm oceanic feature on Hurricane Opal, Mon. Wea. Rev., 128, 1366-1383, doi:10.1175/1520-0493(200zz0) $128<1366$ :EOAWOF $>2.0$. CO;2

Shay, L. K. (2010), Air-sea interactions in tropical cyclones, in Global Perspectives on Tropical Cyclones: From Science to Mitigation, vol. 4, edited by J. C. L. Chan and J. D. Kepert, pp. 93-131, World Scientific Publishing Co., Hackensack, NJ.

Sriver, R. L., M. Huber, and J. Nusbaumer (2008), Investigating tropical cyclone-climate feedbacks using the TRMM Microwave Imager and the Quick Scatterometer, $G^{3}, 9$ Q09V11, doi:10.1029/ $2007 \mathrm{GC} 001842$. 